\title{
Working
}

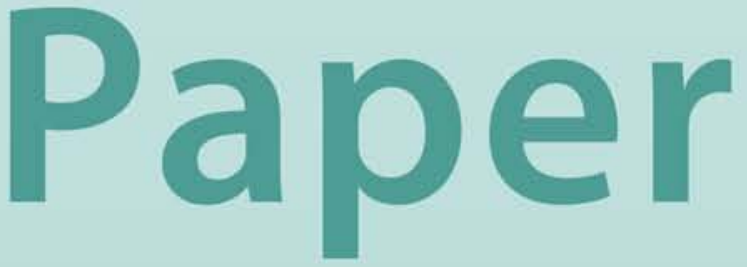




\section{An Analysis of Money Demand and Inflation in the Islamic Republic of Iran}

Oya Celasun and Mangal Goswami 


\title{
IMF Working Paper
}

\author{
Middle Eastern Department
}

\section{An Analysis of Money Demand and Inflation in the Islamic Republic of Iran}

\author{
Prepared by Oya Celasun and Mangal Goswami ${ }^{1}$ \\ Authorized for distribution by Abdelali Jbili
}

December 2002

\begin{abstract}
The views expressed in this Working Paper are those of the author(s) and do not necessarily represent those of the IMF or IMF policy. Working Papers describe research in progress by the author(s) and are published to elicit comments and to further debate.
\end{abstract}

This study examines money demand and inflation dynamics in the Islamic Republic of Iran using quarterly data for the period 1990/91-2001/02 and tests whether the disinflation during 2000/01-2001/02 represents a structural break in the data. A long-run money market equilibrium condition is identified and the short-run behavior of the inflation, measured in terms of non-administered component of the consumer price index (CPI) is modeled conditional on the disequilibria in the money market. Estimation results indicate that the stabilization of the exchange rate on account of strong oil revenues during 2000/01-2001/02 buoyed the demand for domestic money and contributed to the decline in inflation. Tests of model stability do not point to a structural shift in the inflation equation during the period of analysis.

JEL Classification Numbers: C51, E31, E41.

Keywords: Iran, Inflation, Money Demand, Exchange Rate

Authors’ E-Mail Addresses: celasun@imf.org, mgoswami@imf.org

\footnotetext{
${ }^{1}$ We are grateful to Fredric Malek and Payman Ghorbani of the Bank Markazi Joumhouri Islami Iran for discussions and great help with obtaining much of the data used in the analysis. We thank Abdelali Jbili, Vitali Kramarenko, and Jean Le Dem for very useful comments and Alina Milasiute for excellent research assistance. All numerical results were obtained using $P c$ Give version 10.1.
} 
Contents

Page

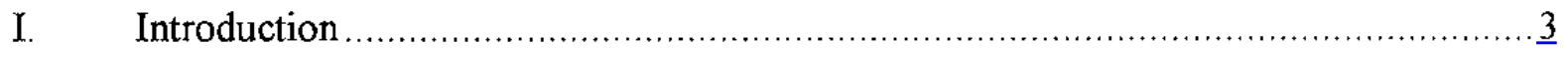

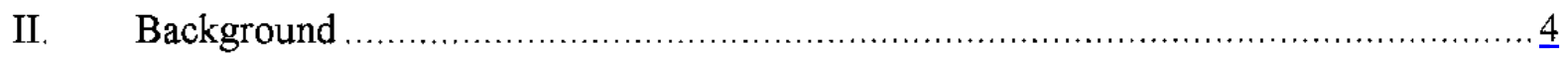

III. Composition and Structure of the Iranian CPI ........................................

IV. Theoretical Framework and Cointegration Analysis $\ldots \ldots \ldots \ldots \ldots \ldots \ldots \ldots \ldots \ldots \ldots \ldots \ldots$

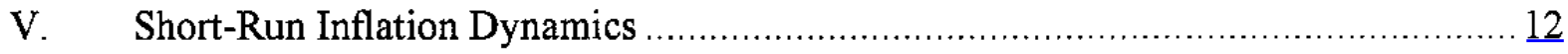

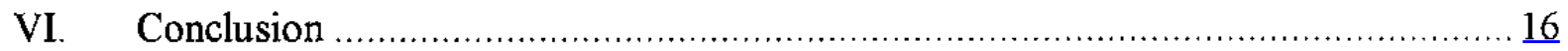

Appendices

I. Data Description and Sources .................................................................. 19

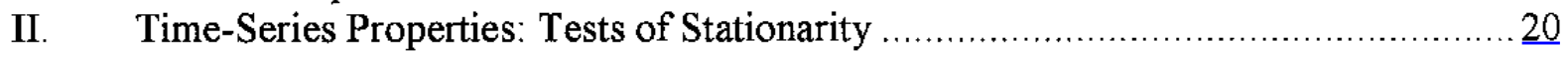

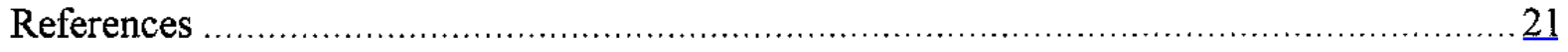

Figures

1. Real Non-Oil Fiscal Deficit, Monetary Developments and Inflation,

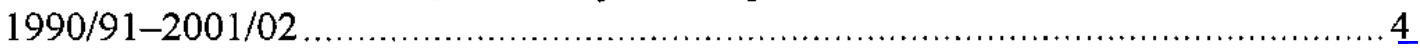

2. Tradables and Nontradables Inflation, 1991-2001 ...................................... $\underline{8}$

3. Administered and Non-Administered CPI Inflation, 1991-2001 ..........................

4. Real M1 Demand and Actual Real M1, 1990:Q1-2001:Q4 ........................... 11

5. Excess Money Supply and the Change in CPI Inflation, 1990:Q4-2001:Q4 .........11

6. Actual and Fitted Changes in Non-Administered CPI Inflation, 1990:Q4-2001:Q4 .14

7. Recursive Estimates of the Estimated Coefficients, 1996:Q2-2001:Q4 .............. 14

8. One-Step Residuals, 1996:Q2-2001:Q4 .............................................. 15

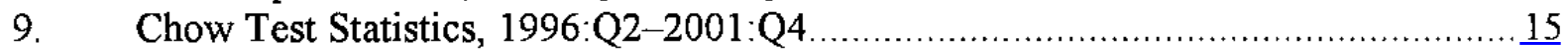

Table

1. Composition of CPI Basket, 1990/91-2001/02 ...................................... I

Appendix Table

1. Unit Root Augmented Dickey-Fuller Test Statistics: 1990:Q3-2001:Q4 .............. 20 


\section{INTRODUCTION}

Inflation in the Islamic Republic of Iran has historically been moderately high, and the main source of inflation in the long run has been the financing of large government deficits by monetary expansion. ${ }^{2}$ Twelve-month inflation in terms of the consumer price index (CPI) was in the double digits throughout the 1990 s, registering an average of 25 percent from 1990/91 to $1999 / 2000 .^{3}$ However, despite sustained high growth of money supply, the period 2000/01-2001/02 witnessed a significant decline in inflation, to an average of about 12 percent (Figure 1).

The marked disinflationary trend has raised the question of whether there has been a structural break in inflation dynamics and whether low inflation can be sustained despite high growth in the monetary aggregates - for instance, by restricting the producer price inflation of the goods and services provided by public sector enterprises. An understanding of the nature of the decline in inflation is crucial to guide monetary policymaking, especially given the increased importance of the latter under the unified exchange rate system. The purpose of this study is to examine money demand and inflation dynamics in Iran based on a quarterly data set for 1990/91-2001/02, and to test the hypothesis of whether the recent disinflationary process has been associated with a structural break in the estimated relationships.

The study estimates a long-run money market equilibrium condition and analyzes the impact of disequilibria in the money market on changes in the inflation of consumer prices that are not administered by the public sector. A long-run money market equilibrium condition is identified in the form of a cointegrating vector among real M1 balances, output, CPI inflation, and the rate of depreciation of the Iranian rial in the parallel foreign exchange market. Given that the rate of inflation is found to be the only variable in the cointegrating relationship which adjusts in response to disequilibrium in the money market, the short-run behavior of the change in the inflation of the non-administered component of CPI is modeled conditional on the disequilibria in the money market and the other variables that potentially impact inflation. ${ }^{4}$ The stability of the estimated inflation equation is analyzed in view of the

\footnotetext{
${ }^{2}$ Liu and Adedeji (2000) present an econometric analysis of money demand and inflation for the period 1989/90-1998/99, and conclude that inflation was mainly a monetary phenomenon.

${ }^{3}$ The Iranian fiscal year begins in March.

${ }^{4}$ While this methodology allows for economic theory to guide the specification of long-run economic relationships, the specification of short-run dynamics is taken to be an empirical matter. See Kuijs (1998) for a useful outline of this methodology with an application to Nigeria.
} 
Figure 1. Real Non-Oil Fiscal Deficit, Monetary Developments, and Inflation, 1990/91-2001/02

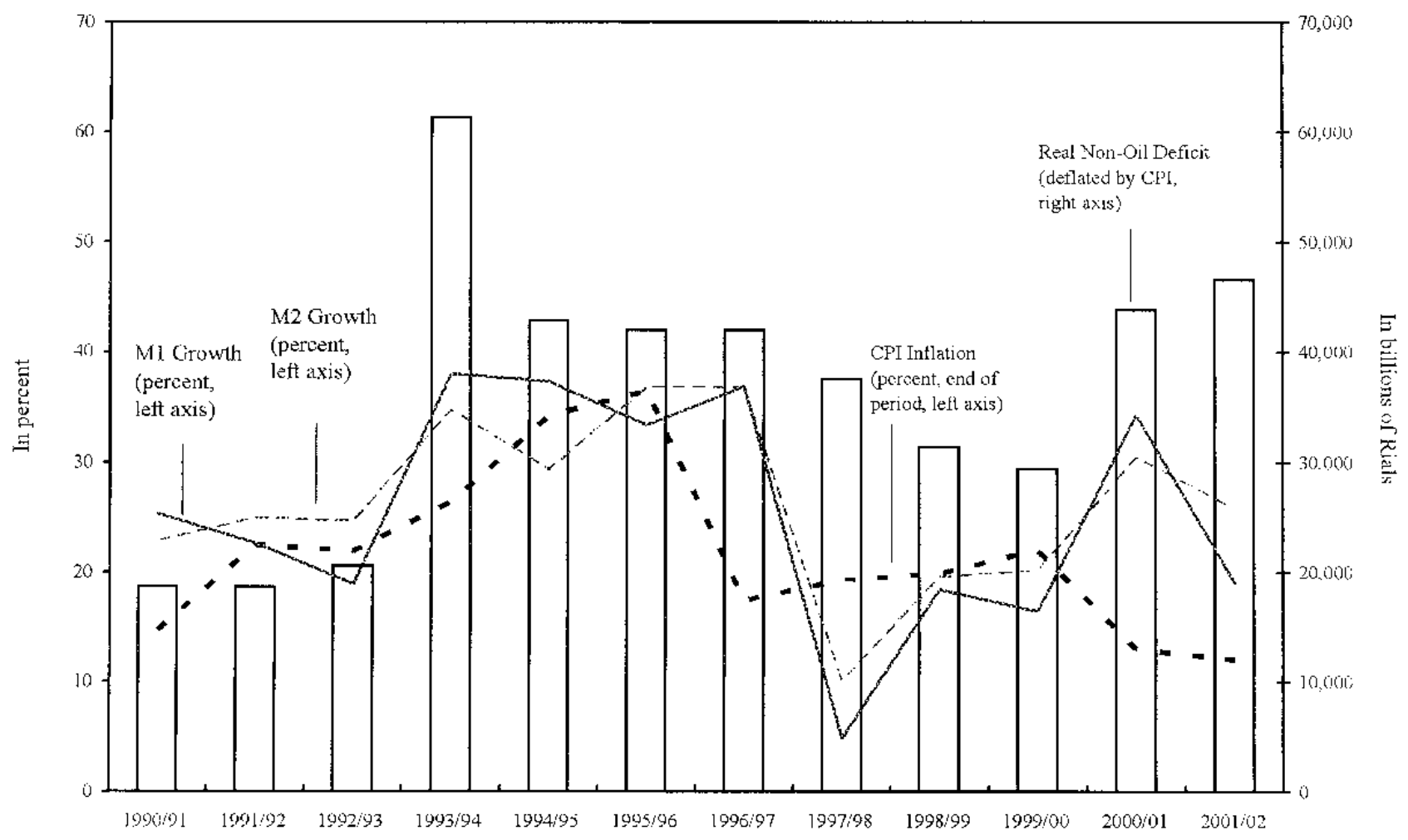

Sources: Iranian authoritics; and IMF staff estimates.

decline of inflation despite the sustained increase in the money stock during the period from 2000/01-2001/02. The results of statistical tests do not point to a structural shift in the equation that governs inflation dynamics.

The paper is structured as follows. Section II briefly overviews the main macroeconomic developments in the Islamic Republic of lran during the period from 1990/91 to 2001/02. Section III describes the composition and structure of the Iranian CPI. Section IV describes the model underlying the analysis and presents the results of the cointegration analysis. Section $V$ presents estimation results for the inflation equation and tests of model stability. Section VI concludes.

\section{BACKGROUND}

The Iranian economy experienced considerable volatility during the 1990s, driven by large external shocks and structural changes induced by shifts in domestic policies relating to the administrative allocation of resources, trade and exchange restrictions, and distortions in the pricing system including exchange rates, interest rates, and domestic energy prices. 
Macroeconomic management in the aftermath of the 1980-88 Iran-Iraq war was largely guided by three successive Five Year Development Plans, starting in the fiscal year 1990/91. While the first two development plans envisaged a bold structural reform agenda to open up the economy and remove impediments to growth, the outcome was not favorable due to the slow implementation of reforms, bunching of scheduled debt repayments, and oil price shocks combined with economic sanctions on international trade and investment. However, the implementation of the current Third Five-Year Development Plan (TFYDP, 2000/01-2004/05) is taking place in an environment of relative macroeconomic stability and a favorable process of consensus building towards reforms.

The postwar reconstruction phase under the First Five-Year-Development Plan was marked by rapid economic growth of over 7 percent during the first two years (1990/911991/92). The sharp economic recovery was mainly driven by public investment programs financed by monetary expansion and short-term external debt, and aided by a policy of economic liberalization. The latter included progress in liberalizing domestic prices and foreign exchange restrictions and culminated in the first attempt at exchange rate unification in March 1993. ${ }^{5}$ However, the overly expansionary financial policies generated large macroeconomic imbalances, and combined with the impact of a negative oil price shock in 1993, led to severe balance of payments problems. In response, a series of measures were undertaken, including the compression of imports, the reinstatement of the multiple exchange rate system and the administrative allocation of foreign exchange. The level of imports was compressed by about 50 percent from its peak in 1991/92 to only US $\$ 13$ billion in 1993/94 and remained relatively low for much of the 1990s.

Against this background, the Second Five Year Development Plan initiated in $1995 / 96$ focused on rationalizing relations with external creditors, containing inflation, and reducing the external debt stock and lengthening its maturity. While expansionary policies were adjusted downward, the intensification of U.S. sanctions following the passage of the Iran-Libya Sanction Act (ILSA) in August 1995 resulted in instability in the macroeconomic setting. This was accentuated by a sharp rise in year-on-year CPI inflation to a peak of 59 percent in May 1995, leading to further tightening of exchange restrictions to stem the run on the foreign exchange market. For much of the 1995/96-1999/2000 period, the economy remained constricted by structural impediments, lack of access to external markets, and excessive compression of imports, which restrained the development and growth of the private sector. As a result, economic performance during the 1993/94-1999/2000 period was weak, with an average overall real GDP growth rate of 3.3 percent and the real non-oil sector growth averaging at 3.7 percent.

The TFYDP was formulated to initiate a broad economic adjustment program aiming at reducing the role of the public sector in the economy, encouraging the development of private sector activities, and liberalizing the trade regime. The Plan's macroeconomic

\footnotetext{
${ }^{5}$ See Sundararajan, Lazarc, and Williams (1998) for an account of the 1993 exchange rate unification.
} 
framework was designed to reduce the unemployment rate to 11.5 percent by $2004 / 05$, by targeting a real GDP growth rate of 6 percent annually. Progress in implementing the ambitious agenda of the TFYDP has been encouraging, and was facilitated by the stabilization of the macroeconomic situation since 1999/2000, strong oil prices since $2000 / 01$, as well as a stronger commitment to fiscal responsibility and an impressive reduction in external debt. The period from 2000/01-2001/02 witnessed a sharp drop in the inflation rate despite sustained strong money growth, mainly on account of the effect of trade liberalization and an increase in real money demand with the stabilization of the foreign exchange market, as will be discussed in the rest of the paper.

\section{COMPOSITION AND STRUCTURE OF THE IRANIAN CPI}

The Iranian CPI covered 346 items from 1990/91-1996/97 and 344 items from 1997/98-2001/02, with slightly different weights in the two subperiods. The subcomponents and their weights in the CPI are summarized in Table 1.

The prices of bread, sugar, vegetable oil, medicines, water, fuel, electricity, interurban bus transport, and inter-city air transport, which have a total weight of about 5.5 percent in the CPI, are subsidized and administered by the government. The inflation of administered prices has been broadly on a decreasing path since $2000: \mathrm{Q} 1$, but has remained higher than overall CPI inflation in 2000 (Figure 2). This suggests that the controlling of administered prices has had little impact on the disinflation process from 2000/01-2001/02. On the other hand, Figure 3 shows that the disinflation was mainly driven by the decline in the inflation of tradable goods prices in the CPI, while nontradables inflation remained relatively stable, suggesting that the stability of the exchange rate and increased import penetration since 2000/01 have contributed to the decline in CPI inflation by reducing the inflation of tradables. ${ }^{6}$

\footnotetext{
${ }^{6}$ Tradablc goods comprise food, beverages and tobacco; clothing and footwear; and household goods, whereas nontradables comprise all remaining items in the CPI.
} 
Table 1. Composition of CPI Basket, 1990/91-2001/02

\begin{tabular}{|c|c|c|}
\hline & \multicolumn{2}{|c|}{ Weights } \\
\hline & 1990/91-1996/97 & 1997/98-2001/02 \\
\hline All ilems & 100 & 100 \\
\hline Food, beverages, and tobacco & 37.33 & 32.45 \\
\hline Food at home & 34.03 & 30.24 \\
\hline Bread, rice, cereal, and grains & 7.53 & 6.10 \\
\hline Dairy products and eggs & 3.79 & 3.84 \\
\hline Meat, poulity, and fish & 8.36 & 7.91 \\
\hline Fruits and vegetables & 10.01 & 7.95 \\
\hline Oils, fats, and sugar products & 2.80 & 2.45 \\
\hline Tea and condiments & 1.52 & 1.99 \\
\hline Food away from home & 1.12 & 0.91 \\
\hline Beverages and tobacco & 2.18 & 1.31 \\
\hline Clothing and footwear & 11.14 & 9.55 \\
\hline Dwelling & 23.64 & 25.41 \\
\hline Water, fuel, and power & 1.54 & 1.63 \\
\hline Household goods and services & 7.16 & 7.22 \\
\hline Transportation and communication & 7.93 & 11.40 \\
\hline Medical care & 3.94 & 4.57 \\
\hline Recreation, education, and culture & 2.02 & 3.53 \\
\hline Personal care and effects & 5.30 & 4.24 \\
\hline \multicolumn{3}{|l|}{ Memorandum items: } \\
\hline Administered CPI & 5.27 & 5.50 \\
\hline Non-administered CPI & 94.73 & 94.50 \\
\hline Tradables & 55.63 & 49.22 \\
\hline Nontradables & 44.37 & 50.78 \\
\hline
\end{tabular}

Sources: Iranian authorities; and IMF staff estimates 
Figure 2. Tradables and Nontradables Inflation, 1991-2001

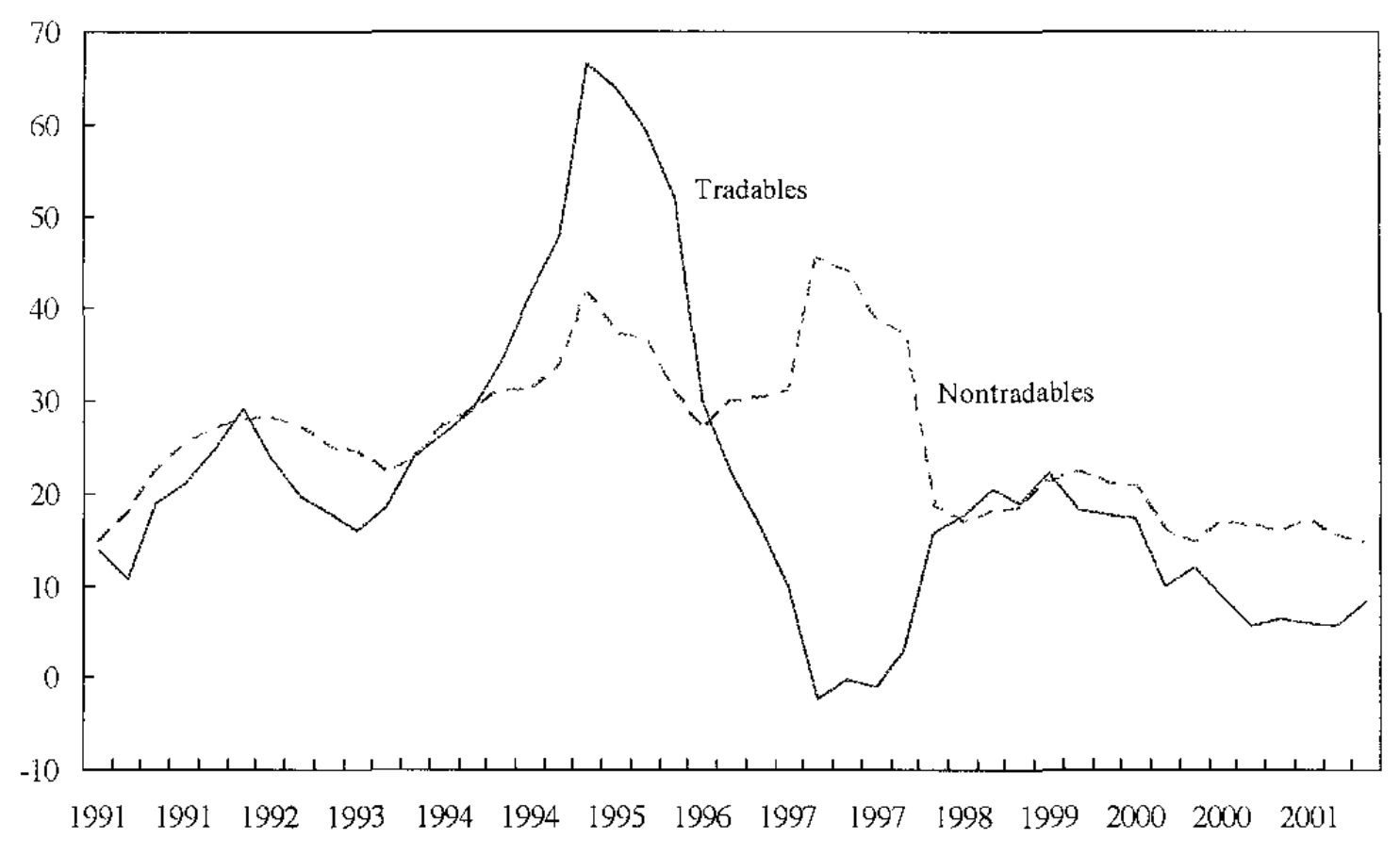

Sources: Iranian authorities; and IMF Staff estimates.

Figure 3. Administered and Non-Administered CPI Inflation, 1991-2001

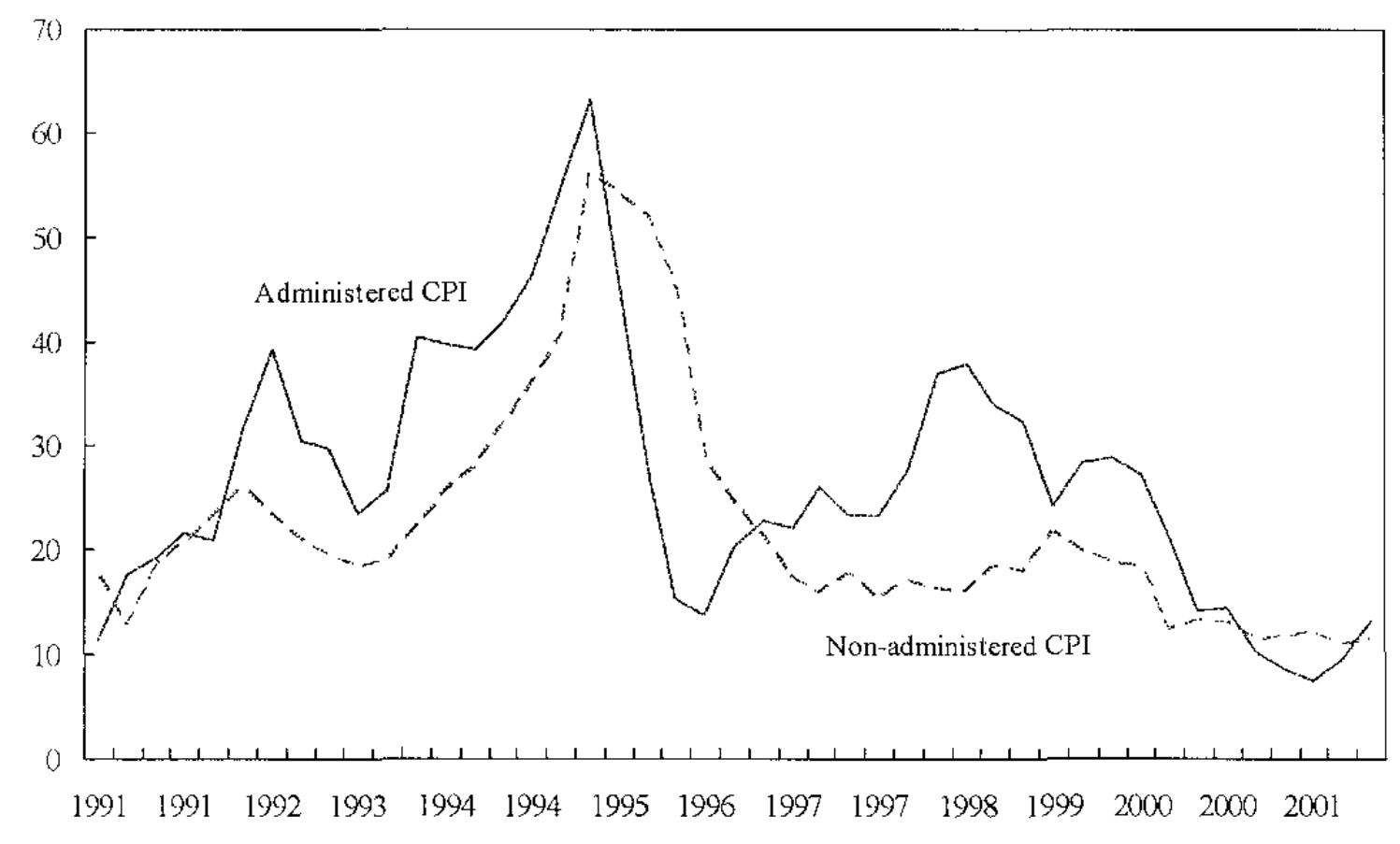

Sources: Iranian authorities; and IMF Staff estimates. 


\section{Theoretical Framework and CoInTEgration Analysis}

The supply of money is assumed to be exogenous. The demand for real monetary balances, $m l p$, is assumed to depend on real GDP (as a proxy for real expenditure), $y$, and a vector comprised of measures of the opportunity cost of holding money. ${ }^{7}$ For the case of narrow money, two such proxies are the rate of inflation, $d c p i$, and the rate of depreciation of the rial against the U.S. dollar in the parallel market, dpar. ${ }^{89}$ The money market equilibrium condition can be stated as:

$$
m 1 p=f(y, d c p i, d p a r)
$$

The disequilibrium in the money market in period $t$ is:

$$
E C M M_{t}=m 1 p_{t}-f\left(y_{t}, d c p i_{t}, d p a r_{t}\right)
$$

The long-run relationship between $m 1 p, y, d c p i$, and $d p a r$ from 1990:Q3-2001:Q4 is estimated in the form of a cointegrating vector, as unit-root tests indicate that all the variables in the relationship are integrated of order one. ${ }^{10}$ The Johansen (1988) trace statistic is used to determine the number of cointegrating vectors among the variables. The trace statistic indicates that there is at most one cointegrating vector at one percent confidence. The estimated long-run money demand equation takes the form:

$$
m 1 p=0.78+0.57 y-0.60 d c p i-1.36 d p a r
$$

A coefficient smaller than unity on output in the long-run money market equilibrium relationship indicates a declining rate of velocity in the long run, which is consistent with the Iranian experience from 1990-2001. ${ }^{11}$ The demand for real money is estimated to be very

\footnotetext{
${ }^{7}$ All the variables are in logarithms. Data description and sources are presented in Appendix A.

${ }^{8}$ The levels of nominal intercst rates are not used as they are administered and fairly constant over much of the sample period.

${ }^{9}$ The parallel market for forcign cxchange is an amalgam of several closely linked and integrated markets, and throughout the sample period, the only foreign exchange market where Yranian agents could obtain forcign currency for most capital account activities, including the purchase of foreign currency as a financial instrument that provides some hedge against domestic inflation.

${ }^{10}$ The results of the unit-root tests are summarized in Appendix B.

"Liu and Adedeji (2000) report an estimated output elasticity of real M2 of 0.63 for a sample from 1989/90 $1998 / 99$ and Pesaran (2000) reports an elasticity of 0.53 for 1979/80-1995/96, both of which are reasonably close to our estimate of 0.57 .
} 
sensitive to the rate of exchange rate depreciation and the rate of inflation. The model predicts that the reversal of the trend of depreciation at the parallel market from the third quarter of 1999 onwards has boosted real M1 demand, indicating that the growth in real M1 from 1999:Q3-2000:Q4 has in fact been exceeded by an increase in the demand for real M1 balances (Figure 4)

Tests of weak stationarity indicate that $y, m l p$, and dpar are weakly exogenous to this co-integrating relationship, implying that the inflation rate, $d c p i$, is the variable in the system which adjusts to the disequilibrium in the money market. ${ }^{12} 13$ This is supported also by graphical evidence. Figure 5 shows the close relationship between the disequilibria in the money market (as captured by the residuals of the money demand equation, ECMM) and the changes in the CPI inflation rate. The changes in the inflation rate impacts the equilibrium in the money market through two channels. First, an increase in the price level decreases the real value of a given level of the outstanding money stock, reducing the excess of supply over demand for nominal monetary balances. Second, and working in the opposite direction, a higher inflation rate, implying a higher opportunity cost of holding domestic currency against goods, reduces the demand for real money, increasing the excess of money supply over money demand. It can be shown, however, that given the estimated magnitudes of the parameters of the money demand function, the net effect of inflation is always to reduce the excess real supply of money, as long as inflation remains above zero. ${ }^{14}$

\footnotetext{
${ }^{2}$ The concept of weak exogeneity is described in Johansen (1992).

${ }^{13}$ The cointegration test was also carricd out for real M2 balances, real output, inflation rate and the parallel market depreciation rate, and the Johansen trace statistic indicated the statistical significance of a single cointegrating vector. However, all variables except the level of real M2 balances were found to be weakly exogenous to the cointegration relationship. Given that inflation was found not to adjust in response to disequilibria in broad money, the level of real Ml balances was used as the relevant measure of money supply.

${ }^{14}$ The condition for a given level of inflation to reduce real moncy supply more than it reduces real money demand is $-0.4 d c p i_{1+1}<0.6 d c p i_{t}$, which is always satisfied for nonnegative rates of inflation.
} 
Figure 4. Real M1 Demand and Actual Real M1, 1990:Q1-2001:Q4

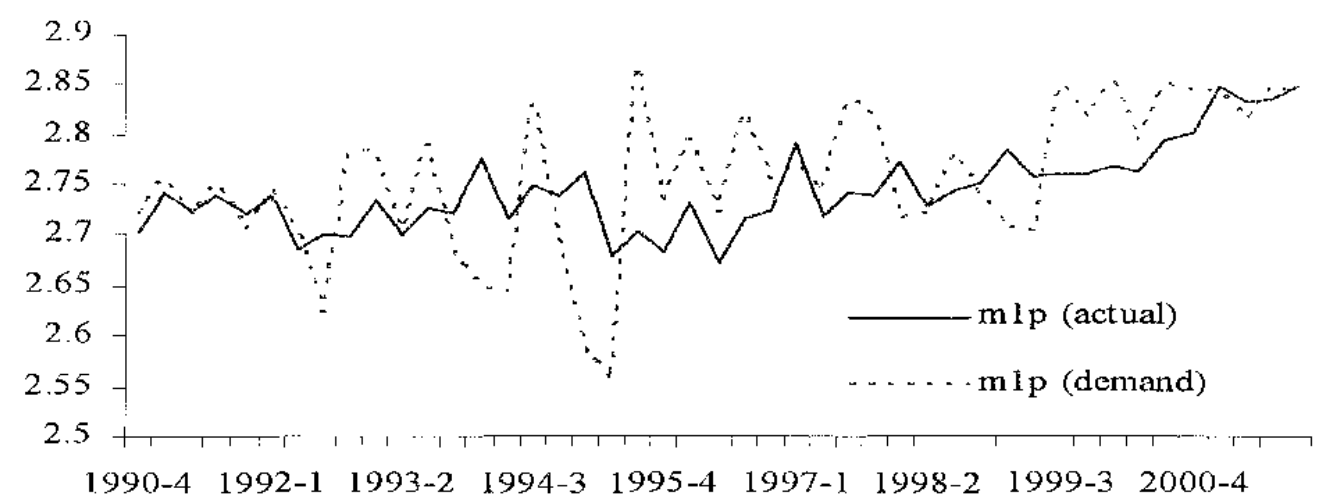

Sources: Iranian authorities; and IMF Staff estimates.

Figure 5. Excess Money Supply and the Change in CPI Inflation, 1990:Q4-2001:Q4

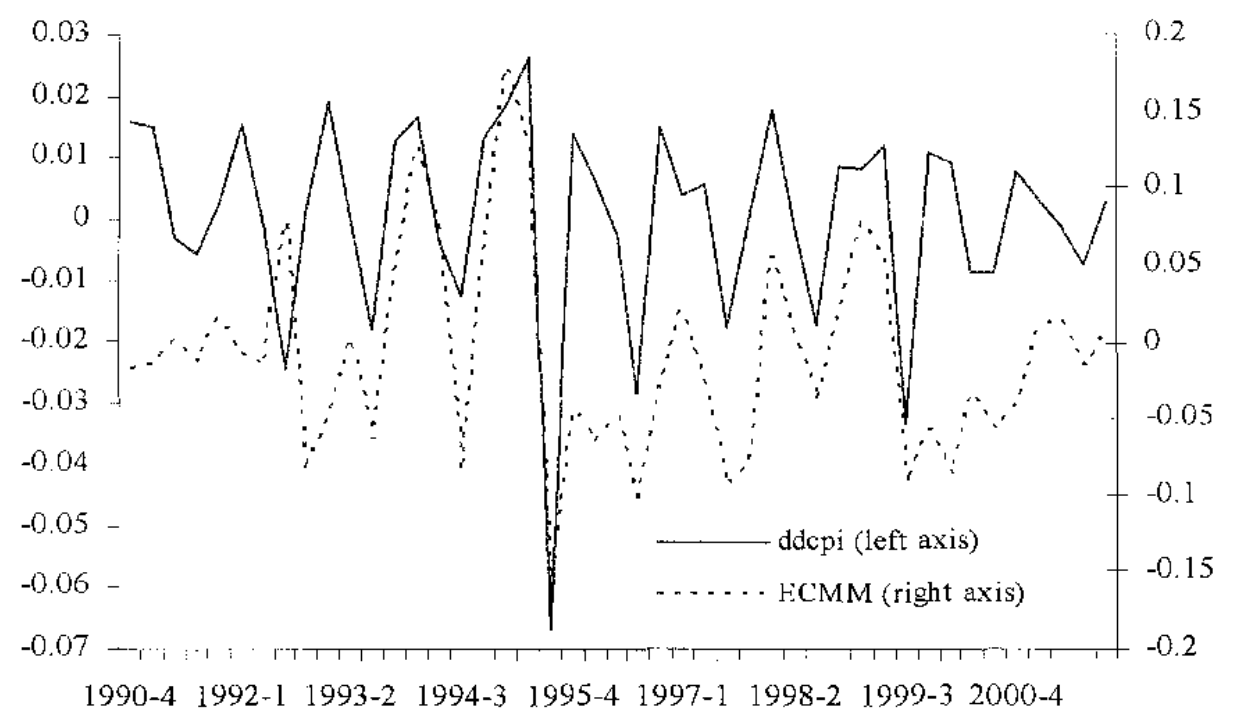

Source: IMF Staff estimates. 


\section{SHORT-RUN INFLATION DYNAMICS}

Given that inflation is the only variable in the money market relationship which is not weakly exogenous to the cointegrating vector, its dynamics can be consistently analyzed by estimating a single error-correction equation. An important consideration in the analysis of Iranian CPI inflation dynamics is that the prices of a number of subsidized goods are administered by the government, and the level of price adjustments are guided mainly by political and social considerations. Since it is the non-administered component of CPI that adjusts to market forces, including disequilibria in the money market, the dependent variable in the equation is taken to be the change in the non-administered component of CPI, while the change in the inflation of the administered component is included as an exogenous variable. ${ }^{516}$ An error-correction equation for the first difference of non-administered CPI inflation $\left(d d c p n i_{t}\right.$ ) which includes as explanatory variables the current values and the four lags of the first difference of real money demand, output, the parallel market depreciation rate, the administered CPI inflation rate, the four lags of the non-administered CPI inflation rate, as well as the first lag of the error correction term, ECMM, is estimated by ordinary least squares. It is worth mentioning that the direct impact of the parallel market exchange rate depreciation on inflation is likely to be associated with two different channels. The first stems from the importance of the market determined exchange rate in the formation of inflationary expectations, as has been the case in many high inflation economies. Second, from early-2000 onwards, the parallel market exchange rate has tracked closely the Tehran Stock Exchange (TSE) rate, which has been the main determinant of imported goods prices-and therefore tradable prices-in the CPI.

By removing the variables with statistically insignificant coefficients from the general error-correction equation, the following specific inflation equation is obtained for the period 1990:Q4-2001:Q4: ${ }^{17}$

$$
\begin{aligned}
d d \text { cpin }_{t} & =\underset{\left(0.001^{* *}\right)}{0.005}-\underset{\left(0.11^{* *}\right)}{0.51} d d \sin _{t-1}-\underset{\left(0.08^{* *}\right)}{0.28 d d c p i n_{t-2}}+\underset{\left(0.02^{* *}\right)}{0.07} d y_{t-1}+\underset{\left(0.02^{* *}\right)}{0.06} d y_{t-2}+\underset{\left(0.02^{*}\right)}{0.03 d y_{t-3}} \\
& +\underset{\left(0.04^{* *}\right)}{0.22} d d p a r+\underset{\left(0.06^{* *}\right)}{0.15} d m 1 p_{t-2}+\underset{\left(0.03^{* *}\right)}{0.13} E C M M_{t-1}-\underset{\left(0.01^{* *}\right)}{0.02} Q 3 .
\end{aligned}
$$

\footnotetext{
${ }^{15}$ The non-administered component of CPI excludes the prices of bread, sugar, vegetable oil, medicines, water, fuel, electricity, inter-urban bus transport and inter-city air transport, which comprise about 5 percent of the consumer price index basket.

${ }^{16}$ Taking the change in overall CPI as the dependent variable does not change any of the subsequent results, including those relating to the stability of the model.

${ }^{17}$ The exclusion restrictions were tested at each stage of the model reduction and only statistically insignificant restrictions were accepted.
} 
The coefficients in the equation have the expected sign and are highly significant. ${ }^{18}$ The change in the administered component of CPI inflation is omitted from the equation as it does not impact non-administered inflation significantly, most likely because expenditures on subsidized goods and services constitute only a minor share of consumer and firm budgets given their very low prices, and therefore changes in these administered prices do not have significant cost-push effects. The first two lags of the change in inflation enter with large negative coefficients, reflecting the tendency for mean reversion in the change of inflation, which is a stationary variable. The seasonal dummy variable for summer months is significantly negative, indicating that inflation declines during the summer, most likely due to the increased supply of agricultural food products. The three lags of output growth enter the inflation equation with positive coefficients, suggesting that increased real income and aggregate demand have inflationary consequences in the short run. Lagged excess monetary balances, twice lagged real money and the contemporaneous rate of parallel market exchange rate depreciation have a positive impact on inflation. The fitted and actual values of the rate of change of inflation are graphed in Figure 6.

The model appears to fit the data quite well, and the residuals for the period 2000-01 do not appear to be excessive. To statistically test the stability of the equation over time, a number of recursive tests were carried out. First, the coefficients of the equation were estimated for the sample ranges from 1990:Q4-1995:Q4 to 1990:Q1-2001:Q1. The estimated coefficients for these samples are plotted against the sample end-point in Figure 7. Most of the coefficients and their standard error bands flatten out as the sample is extended, despite a slight instability in some parameters after 2000:Q1, suggesting no statistically significant change in parameters. One step residuals, where the residual in period $t$ is obtained by estimating the model over the sample from 1990:Q4 up to period $t$ are plotted in Figure 8. There are no residuals outside the two standard error bands, implying no outliers, which supports the hypothesis of the constancy of the coefficients. However, the residuals in 2000-01 seem to be somewhat larger than the residuals in the previous periods.

Further, three types of Chow-forecast tests were carried out for the subsample 1995:Q4 to 2001:Q4. Intuitively, these procedures test model stability by comparing the within and post sample residual variances. The first test, the 1-Step Chow test compares the one-step ahead forecast error variance for all sample points after the given initialization period with the error variance within the sample. The Break-point Chow test and the Forecast Chow tests compare the out-of-sample forecast error variance for varying forecast horizons with the within sample error variance. The 1-Step Chow statistic test is plotted in the first panel of Figure 9. The Break-point and the Forecast Chow tests for regressions with the forecast horizon decreasing from 1995:Q1-2001:1 to 1995Q:1 and increasing from 1995:Q1 to $1995: \mathrm{Q} 1-2001: \mathrm{Q} 1$ are presented in the second and third panels of Figure 9 , respectively.

\footnotetext{
${ }^{18}$ Standard errors are in parentheses. Asterisks * and $* *$ denote statistical significance of the coefficients at the 1 and 5 percent levels, respectively.
} 
Figure 6. Actual and Fitted Changes in Non-Administered CPI Inflation, 1990:Q4-2001:Q4

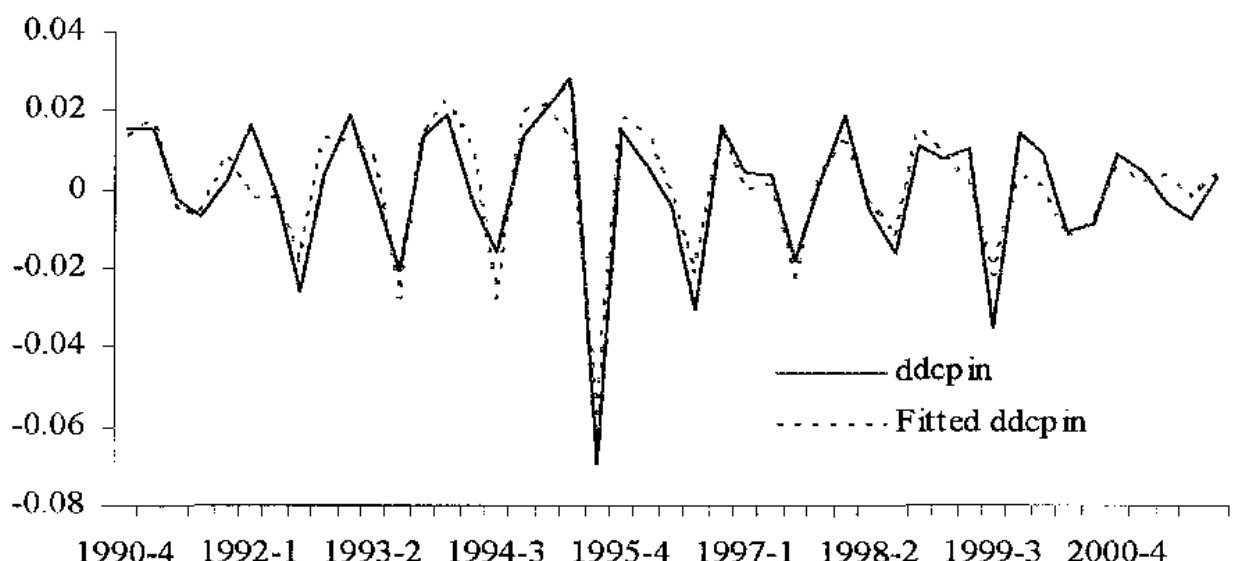

Source: IMF Staff estimales.

Figure 7. Recursive Estimates of the Estimated Coefficients, 1996:Q2-2001:Q4
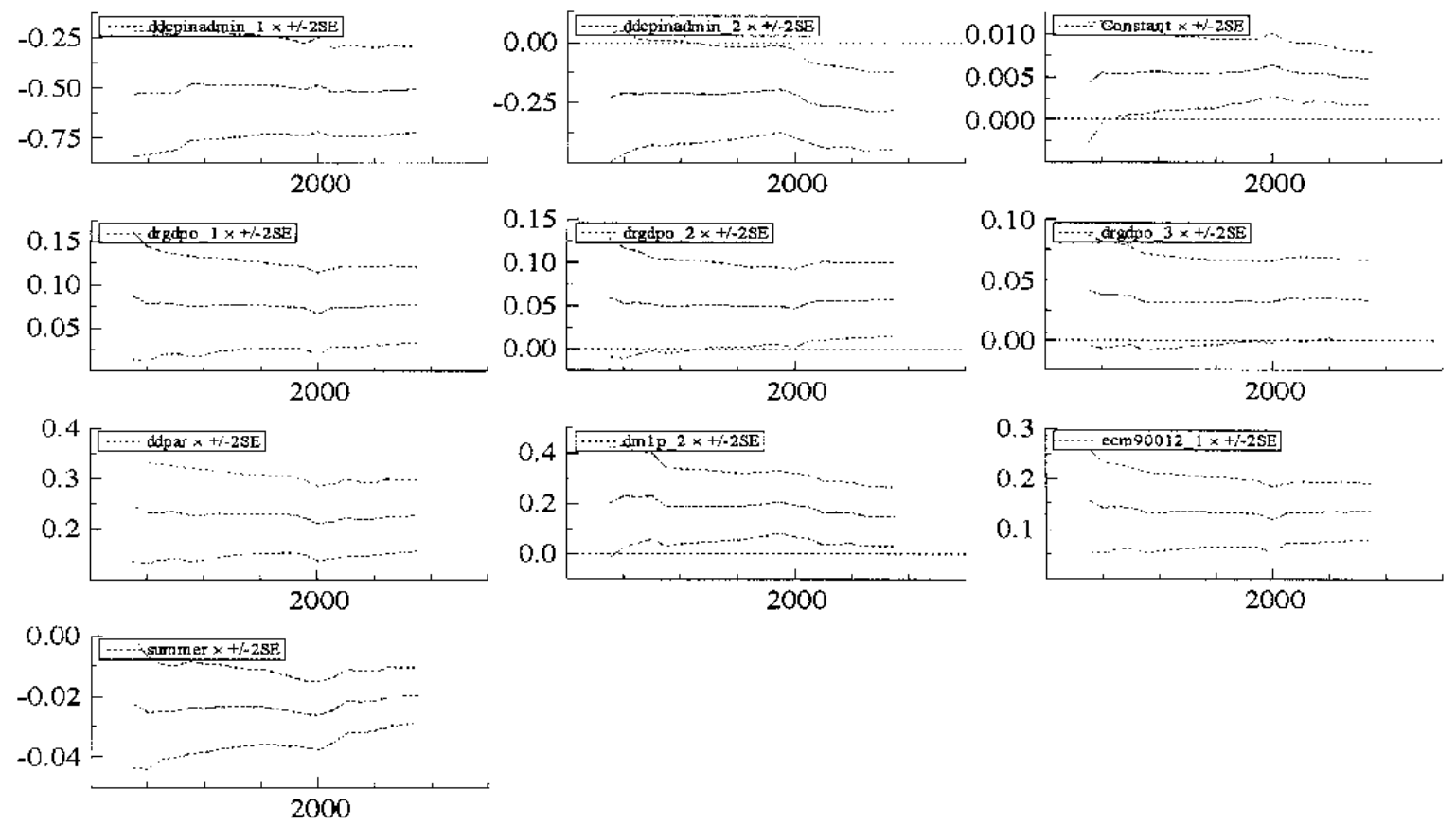

Source: IMF Staff estimates. 
Figure 8. One-Step Residuals, 1996:Q2-2001:Q4

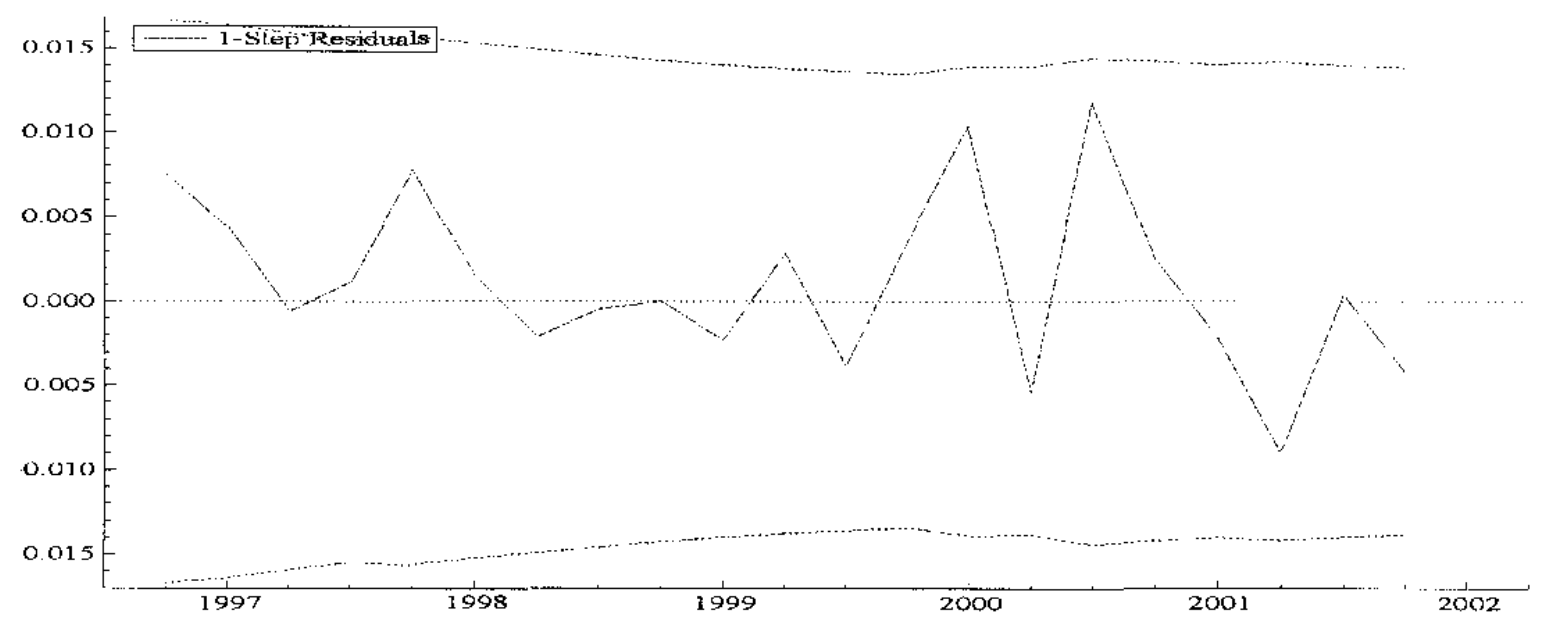

Source: IMF Staff estimates.

Figure 9. Chow Test Statistics, 1996:Q2-2001:Q4
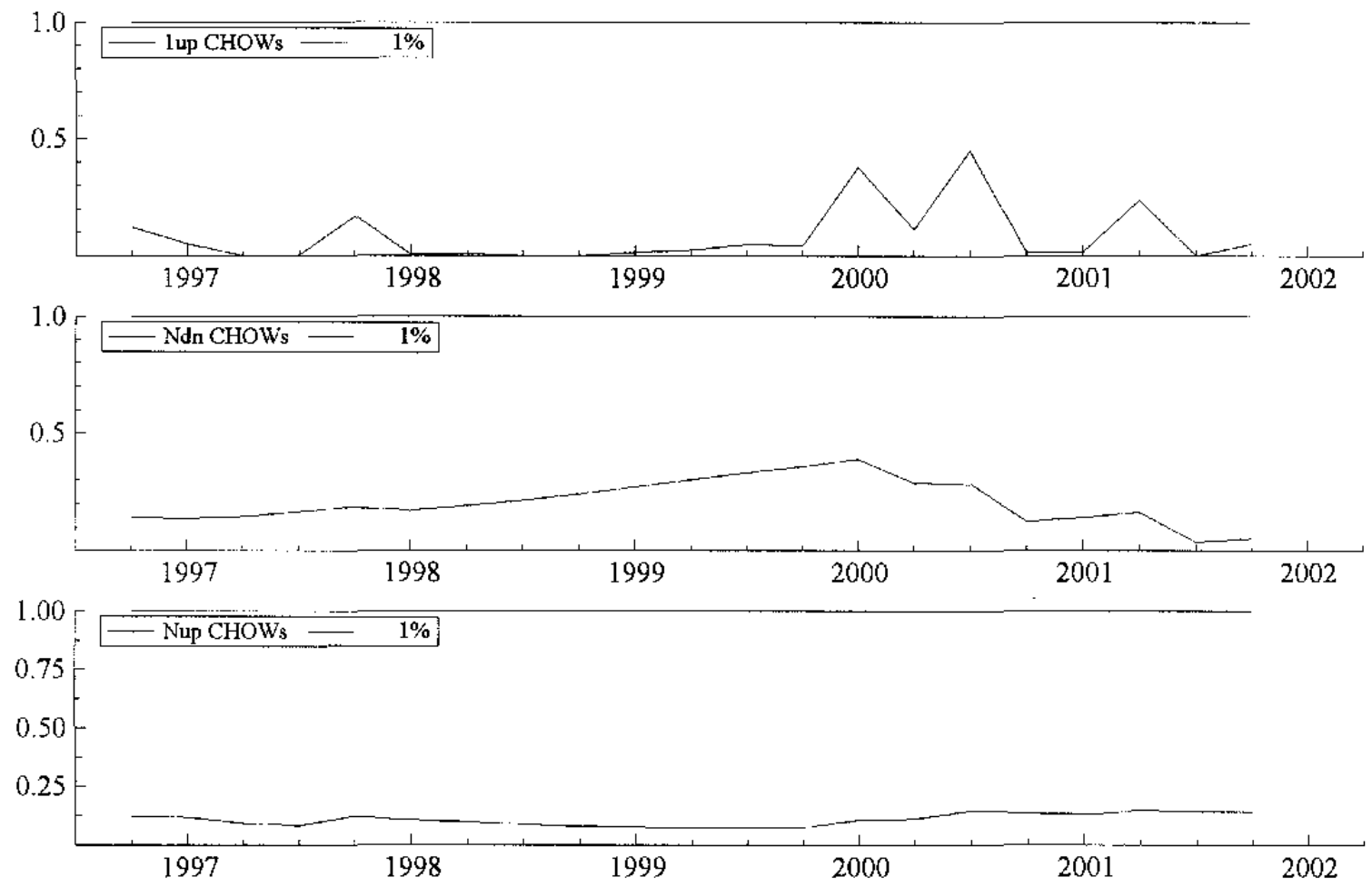

Source: IMF Staff estimates. 
The one percent significant values of the test statistic are normalized to one (as an adjustment to the varying degrees of freedom). The test statistics never exceed one, implying no rejection of the hypothesis of model constancy over the sample period.

\section{Conclusion}

This study presents a simple quarterly econometric model of long-run money demand and short-term inflation dynamics in Iran from 1990-2001, and analyzes whether the decline in inflation since early-2000 against a background of strong monetary growth represents a structural break in the modeled relationships. It is first established that real M1 balances have a long-run relationship with real output and a vector of opportunity cost variables proxied by the inflation rate and the rate of depreciation of the rial against the dollar in the parallel market. The estimated money demand equation indicates that the reversal of the trend of depreciation at the parallel market and high output growth have boosted the demand for real M1 after mid-1999, implying that the strong growth of the M1 stock from 2000-2001 has not resulted in large excess liquidity supply and inflationary pressures. It is estimated that the inflation rate adjusts to money market disequilibrium in the short-run, and the estimated error-correction model for the inflation rate shows that lags of the first differences in inflation, output, depreciation of the parallel market rate and the money market disequilibrium term are all statistically significant determinants of the CPI inflation rate.

A battery of stability tests and break-point tests are carried out to gauge whether there was any structural change in inflation dynamics during the latter part of the sample. All tests point to the relative stability of the coefficients and stable forecast error variances, indicating a lack of statistical evidence towards a structural break in inflation dynamics. This implies that the behavior of inflation in 2000-2001 has been consistent with the relationship of inflation with its determinants over the past decade.

The estimated model suggests that the disinflationary process from 2000-2001 was mainly effected by the stable and slight appreciation trend of the parallel market exchange rate, which appears to have a strong influence on inflationary expectations. In addition to its role in curbing inflationary expectations in the short term, the appreciation trend of the parallel exchange rate has led to an increase in the relative real rates of return on domestic currency denominated assets, which, combined with strong output growth, is estimated to have buoyed the demand for domestic currency to the extent that the growth of money supply did not result in a significant money market disequilibrium, in effect reducing the inflationary impact of the growth in money supply. ${ }^{19}$

\footnotetext{
${ }^{19}$ In the period ahead, the empirical relevance of the parallel market exchange rate for inflation is likely to decrease and to be replaced by that of the official rate. The ongoing process of opening to international trade is likely to increase the direct effect of the official exchange rate on CPI inflation. Also, as foreign currency transactions for capital account purposes are gradually liberalized and shifted to the official market, the relevance of the parallel market for asset substitution purposes might diminish.
} 
A number of other factors that have not been captured in our model due to the lack of adequate data are also likely to have exerted downward pressures on CPI inflation. First, favorable weather conditions in 2000 and 2001 have led to strong agricultural output and reduced the inflation of agricultural food prices, which amounted to a total weight of 31 percent in the CPI. Second, the gradual easing of trade barriers and increased import penetration have relaxed supply constraints in the tradables sector, and the stability of the Iranian rial against the U.S. dollar in the official foreign exchange market and the strength of the U.S. dollar against other currencies have curbed the relative price of imports. ${ }^{20}$ With increased competition from imports despite the remaining tariff protection, domestic producers of tradables appear to have had little scope to raise prices, bringing the inflation of tradable consumer goods to single digit levels in the fiscal year 2001/02. ${ }^{21}$ Finally, the annual price increase limit applied to goods and services provided by public sector enterprises was reduced from 25 to 10 percent from March 2000 onwards. As supported by the lack of any statistically significant structural change in inflation dynamics during 2000 , these price controls alone are unlikely to have been binding in significantly altering the inflation rate, but they might have had some restraining impact.

The results of the analysis indicate that a strong increase in the demand for real monetary balances on account of a marked increase in the relative rate of return on domestic currency assets appears to have alleviated the inflationary impact of the nominal money supply growth from 2000/01-2001/02. However, there seems to be little scope for much further growth in real money demand in the future, as it is unlikely that the relative rates of return on Iranian rial assets can increase any further. Given that the stock of real M1 appears to be close to the equilibrium rate at the end of our sample period, this implies that continued strong money supply growth can rapidly lead to disequilibrium in the money market and put upward pressure on inflation.

The estimated model indicates that the exchange rate is a significant determinant of inflation. In the period ahead, any portfolio reallocation away from domestic currency holdings prompted by a perceived unsustainability of the policy stance could increase the parallel market premium given the relatively closed capital account, and translate into higher inflation. In this context, the building-up of disequilibria and misalignments relating to relative prices and the real exchange rate during periods of booming domestic demand would necessitate sharper exchange rate and inflation adjustments when external and domestic

\footnotetext{
${ }^{20}$ From mid-1999 until the March 2002 exchange rate unification, all imported goods excluding imports of subsidized goods were imported at the TSE exchange rate. Following March 2002, most imports were applied the official exchange rate prevailing at the interbank market for foreign exchange, but essential imports were subsidized. Both the TSE exchange rate during 2000-2002 and the interbank rate after March 2002 were very stable.

${ }^{21}$ This effect is likely to have been partially captured by our model, as the stability of the TSE and interbank exchange rates during the period from 2000-2002 was matched by the stability of the parallel rate, which is included as an explanatory variable in the model.
} 
conditions become less favorable, underscoring the need to avoid imprudent fiscal and monetary policies even if their adverse effects are not immediately felt in the form of higher inflation.

Future work could usefully extend the analysis to a general equilibrium setting, where the determinants of inflation, the real exchange rate, and output could be explored in a multivariate framework. This would be useful in understanding whether and how inflation adjusts to disequilibria in the foreign exchange and goods markets as well as the money market. 


\section{Appendix I. Data Description and Sources}

\begin{tabular}{|c|c|c|}
\hline Variable & Description & Source \\
\hline$M 1$ & Narrow money & International Financial Statistics \\
\hline$C P I$ & Consumer Price Index & National Authorities \\
\hline$m 1$ & Logarithm of M1 & \\
\hline$c p i$ & Logarithm of CPI & \\
\hline$m l p$ & Real Mldemand; $\mathrm{ml}$ - cpi & \\
\hline$d c p i$ & Inflation, first difference of cpi & \\
\hline$d d c p i$ & First difference of dcpi & \\
\hline$d c p i n^{*}$ & $\begin{array}{l}\text { Logarithm of the non-administered } \\
\text { subcomponent of CPI }\end{array}$ & \\
\hline ddcpin & First difference of dcpin & \\
\hline dpar & $\begin{array}{l}\text { First difference of the logarithm of the } \\
\text { parallel market exchange rate }\end{array}$ & National authorities \\
\hline ddpar & First difference of dpar & \\
\hline$y$ & Logarithm of real GDP & National authorities \\
\hline$d y$ & GDP growth rate, first difference of $y$ & \\
\hline
\end{tabular}

* The non-administered subcomponent of $\mathrm{CPI}$ is obtained by subtracting the administered component from overall CPI. The administered component was made up of the following items and weights from 1997/982001/02: bread, 1.03 percent; sugar, 0.55 percent; vegetable oil, 0.9 percent; medicines, 1.1 percent; water, 0.35 percent; fuel, 0.81 percent; electricity, 0.47 percent; inter-urban bus transport, 0.27 percent; and inter-city air transport 0.13 percent. Slightly different weights were applied for the period from 1990/91-1996/97. 


\section{Appendix II. Time-Series Properties: Tests of Stationarity}

1. This study uses a cointegration approach to identify a long-run equilibrium relationship in the money market in Iran. A set of variables which are integrated of order one (I(1)) are said to be cointegrated with each other if there is at least one linear combination of these variables which is stationary $(\mathrm{I}(0))$. The order of integration of the variables which enter the money market equilibrium relationship given in equation (3) (m1p, y, dcpi, dpar) was investigated using the Augmented Dickey-Fuller (1979) and Phillips-Perron (1988) tests. $^{22}$ For all the variables except $y$, the hypothesis of nonstationarity cannot be rejected at 5 percent confidence by at least one of the tests. The stationarity of $y$ is rejected only at 10 percent confidence, but for samples ending before $2001: \mathrm{Q} 4$, at higher levels of confidence. For the first differences of the same variables, the hypothesis of nonstationarity is rejected at least 10 percent confidence, suggesting that the variables are I(1). Table 1 presents a summary of the unit-root test results based on the Augmented Dickey-Fuller (1981) procedure.

Table 1. Unit Root Augmented Dickey-Fuller Test Statistics: 1990:Q3-2001:Q4

\begin{tabular}{lcccc}
\hline & \multicolumn{2}{c}{ Level } & \multicolumn{2}{c}{ First Difference } \\
\cline { 2 - 5 } & Lag & Test statistic & Lag & Test statistic \\
\cline { 2 - 5 } m1p & 6 & -0.46 & 6 & $-4.48^{* *}$ \\
Y & 5 & $-3.42^{*}$ & 5 & $-4.16^{* *}$ \\
Dcpi & 6 & -2.35 & 4 & $-3.65^{* *}$ \\
Dpar & 5 & -2.35 & 5 & $-3.26^{*}$ \\
dcpin & 6 & -2.46 & 6 & $-3.66^{* *}$ \\
\hline
\end{tabular}

Notes: Variables are as defined in the text. The test statistic is the coefficient of the first lag of the variable in a regression of first difference of the variable on its lags and a constant term, divided by its standard error. The criteria for lag selection is a modified version of the Akaike information criterion, as described by Pantula et. al. (1994). The critical values of the tests are taken from MacKinnon (1994). The asterisks * and ** indicate that the test statistic is significant at the 5 percent and 10 percent levels, respectively.

\footnotetext{
${ }^{22}$ Two versions of the tests were carried out, by allowing a constant, and a constant and a trend to enter the equations. The test results were not significantly different for the two versions, and only the tests including a constant term are reported in the paper.
} 


\section{References}

Dickey, David A. and Wayne A. Fuller, 1981, "Likelihood Ratio Statistics for Autoregressive Time Series with a Unit Root," Econometrica, Vol. 49 (June), pp. $1057-72$.

Johansen, Søren, 1988, "Statistical Analysis of Cointegration Vectors," Journal of Economic Dynamics and Control, Vol. 12 (June-September) pp. 231-54. ,1992, "Testing Weak Exogeneity and the Order of Cointegration in U.K. Money Demand Data," Journal of Policy Modeling, Vol. 14, (June) pp. 313-34.

Kuijs, Aloysius, 1999, "Determinants of Inflation, Exchange Rate and Output in Nigeria," IMF Working Paper 99/160 (Washington: International Monetary Fund).

Liu, Olin, and Olimuyiwa Adedeji, 2000, "Determinants of Inflation in the Islamic Republic of Iran: A Macroeconomic Analysis," IMF Working Paper 00/127 (Washington: International Monetary Fund).

MacKinnon, James G., 1994, "Approximate Asymptotic Distribution Functions for UnitRoot and Cointegration Tests," Joumal of Business and Economic Statistics, Vol. 12 (April), pp. 167-76.

Pantula, Sastry G., Graciela Gonzales-Farias, and Wayne A. Fuller, 1994, "A Comparison of Unit Root Test Criteria," Journal of Business and Economic Statistics, Vol. 12 (October), pp. 449-59.

Pesaran, Hashem M., 2000, "Economic Trends and Macroeconomic Policies in PostRevolutionary Iran," in The Economy of Iran: Dilemmas of an Islamic State, led by Parvin Alizadeh (London: I.B. Tauris), Chapter 2, pp. 63-100.

Phillips, Peter C.B., and Pierre Perron, 1986, "Testing for a Unit Root in Time Series Regression", Centre de Recherche et Development en Economique (Canada: Universite de Montreal, Vol. 2,186 (June), pp. 1-31.

Sundararajan, V., Michel Lazare, and Sherwyn Williams, 1999, "Exchange Rate Unification, the Equilibrium Real Exchange Rate, and the Choice of the Exchange Rate Regime: The Case of the Islamic Republic of Iran," IMF Working Paper 99/15 (Washington: International Monetary Fund). 